\title{
PENGARUH STRES KERJA, KEPUASAN KERJA DAN KOMITMEN ORGANISASIONAL TERHADAP TURNOVER INTENTION PADA KARYAWAN
}

\author{
Ni Kadek Windi Septia Ningsih ${ }^{1}$ \\ Made Surya Putra ${ }^{2}$ \\ 1,2 Fakultas Ekonomi Dan Bisnis Universitas Udayana (Unud), Bali, Indonesia \\ email: septianingsih@yahoo.com
}

\begin{abstract}
ABSTRAK
Penelitian ini dilakukan pada Toya Devasya Natural Hot Spring \& Camping Resort yang berlokasi di jalan puri bening (STA), toya bungkah, kintamani, Bangli, Bali.Jumlah responden pada penelitian ini adalah karyawan kontrak yang berjumlah 102 orang. Pengumpulan data dalam penelitian ini adalah dengan penyebaran kuesioner yang menggunakan skala likert 5 point untuk mengukur 16 indikator. Teknik analisis data yang digunakan adalah analisis regresi linier berganda. Turnover intention adalah keinginan karyawan untuk menarik diri dari tempat ia bekerja. Turnover intention yang tinggi akan berdampak buruk bagi organisasi oleh sebab itu harus diperhatikan beberapa variabel yang mempengaruhi turnover intention. Penelitian ini bertujuan untuk 1. Mengetahui pengaruh stres kerja terhadap turnover intention, 2. Mengetahui pengaruh kepuasan kerja terhadap turnover intention, 3. Mengetahui pengaruh komitmen organisasional terhadap turnover intention.
\end{abstract}

Kata kunci: stres kerja, kepuasan kerja, komitmen organisasional, turnover intention

\section{ABSTRACT}

This research was conducted at the Toya Devasya Natural Hot Spring \& Camping Resort, located in puri bening road (STA), toya bungkah, kintamani, Bangli, Bali. The number of respondents in this study were 102 contract employees. Data collection in this study is by distributing questionnaires using a 5-point Likert scale to measure 16 indicators. The data analysis technique used is multiple linear regression analysis. Turnover intention is the desire of employees to withdraw from where they work. A high turnover intention will have a bad impact on the organization, therefore it must be considered several variables that affect turnover intention. This study aims to 1. Know the effect of work stress on turnover intention, 2. Know the effect of job satisfaction on turnover intention, 3. Know the effect of organizational commitment on turnover intention.

Keywords: work stress, job satisfaction, organizational commitment, turnover intention 


\section{PENDAHULUAN}

Kondisi lingkungan perusahaan yang sering mengalami perubahan baik eksternal maupun internal membuat perusahaan harus beradaptasi dengan lingkungan yang penuh persaingan. Organisasi harus mampu bertahan dalam situasi yang tidak pasti yang dipengaruhi oleh sumber daya manusia (SDM) yang menjalankannya. Dalam sebuah organisasi kemampuan untuk mempertahankan karyawan yang kompeten sangat penting terutama karyawan yang memiliki loyalitas terhadap perusahaan sehingga dapat membantu perusahaan dalam mencapai tujuannya.

Sumber daya manusia sangat dibutuhkan dalam perusahaan terutama SDM yang memiliki kualifikasi cakap, mudah beradaptasi memiliki inisiatif yang tinggi serta mampu menyelesaikan tugas yang diberikan atasan sebaik mungkin. Potale dan Uhing (2015) menyatakan sumber daya manusia merupakan salah satu keunggulan bersaing perusahaan dalam efisiensi, efektivitas, dan fleksibilitas perusahaan dalam mencapai tujuannya. Ardana dkk. (2012:3) menyatakan bahwa sumber daya manusia adalah harta atau aset yang paling berharga dan paling penting dimiliki oleh suatu organisasi karena keberhasilan organisasi ditentukan oleh sumber manusia. Kemampuan suatu organisasi untuk dapat bertahan dalam jangka panjang ditentukan oleh sumber daya manusia terutama dalam menghadapi kondisi persaingan yang semakin ketat. Agar tujuan perusahaan dapat tercapai maka karyawan dalam perusahaan harus diperhatikan dengan baik agar apa yang ia lakukan untuk perusahaan setimpal dengan apa yang ia dapatkan terutama dalam kenyamanan bekerja sehingga karyawan tidak berniat untuk keluar dari perusahaan dikarenakan kurangnya perhatian dari perusahaan itu sendiri.

Tingginya tingkat turnover intention (keinginan karyawan untuk keluar) telah menjadi masalah serius bagi banyak perusahaan, dimana dampak negatif yang dirasakan oleh perusahaan adalah sulitnya mendapatkan kualitas dan kemampuan yang sesuai dengan kualifikasi yang telah ditetapkan oleh perusahaan, serta dibutuhkannya banyak waktu dan biaya dalam perekrutan karyawan baru (Waspodo et al., 2013). Turnover intention merupakan persepsi negatif karyawan terhadap pekerjaannya yang mana memiliki potensi untuk meninggalkan organisasi apabila mereka merasa tidak senang dan lelah dalam bekerja (Khan et al., 2014). Turnover intention dapat berdampak buruk bagi sebuah organisasi karena terciptanya ketidakpastian dan ketidakstabilan terhadap kondisi tenaga kerja yang ada serta timbulnya biaya yang tinggi untuk pelatihan dan rekrutmen. Hassan (2014) menyatakan bahwa keinginan berpindah kerja atau turnover intention dapat dipengaruhi oleh stres kerja, kepuasan kerja dan komitmen organisasional. Turnover intention merupakan keadaan dimana pekerja memiliki niat atau kecenderungan yang dilakukan baik secara sadar untuk mencari pekerjaan di organisasi lainnya (Abdillah, 2012).

Syahronica et al. (2015) menyatakan stres kerja berpengaruh positif terhadap turnover intention, semakin tinggi tingkat stres maka tinggat turnover intention akan semakin meningkat. Putra \& Wibawa (2014) menyatakan bahwa stres kerja adalah suatu kondisi tertekan yang dialami karyawan dalam pekerjaannya baik dari tugas, pimpinan maupun lingkungan kerjanya. Stres yang terjadi dan tidak bisa diatasi dengan baik biasanya berakibat pada 
ketidakmampuan seseorang berinteraksi secara positif terhadap lingkungannya, baik lingkungan luar maupun lingkungan didalam perusahaan (Budiyono, 2016). Chandio \& Javed (2015) menyatakan ketika stres kerja meningkt maka akan menyebabkan timbulnya keinginan keluar yang ada pada diri karyawan. Manurung dan Ratnawati (2012) ketika tingkat stres semakin tinggi dan parah, maka stres bisa membuat karyawan menjadi sakit dan bahkan akan mengundurkan diri (turnover).

Selain stres kerja faktor lain yang mempengaruhi turnover intention adalah kepuasan kerja, kepuasan kerja adalah suatu keadaan yang berkaitan dengan reaksi emosional dari pandangan seseorang yang telah mendapatkan kebutuhannya dari pekerjaan yang dilakukan, sehingga ketika karyawan merasa nyaman dalam bekerja dan mampu mengembangkan potensi yang dimilikinya, dalam arti memberikan tantangan maka hal tersebut akan menjadi indikator kepuasan kerja yang baik (Darmawati \& Indartono, 2015). Robbins \& Judge (2017) menyatakan kepuasan kerja merupakan sikap umum seorang individu atau karyawan terhadap pekerjaannya. Indrayanti \& Riana (2016) menyatakan kepuasan kerja berpengaruh negatif terhadap turnover intention dimana semakin puas karyawan dalam bekerja maka mereka akan berusaha untuk tetap berada di dalam organisasi. Kepuasan kerja adalah suatu keadaan yang berkaitan dengan reaksi emosional dari pandangan seseorang yang telah mendapatkan kebutuhannya dari pekerjaan yang dilakukan, sehingga jika karyawan merasa kebutuhannya terpenuhi maka karyawan akan tetap bertahan dalam perusahaan tersebut karena merasa nyaman dalam bekerja (Dizgah et al., 2012)

Komitmen organisasional juga merupakan faktor penting dalam keberhasilan suatu organisasi dimana semakin kuat seorang karyawan ingin bertahan dalam organisasi maka semakin rendah keinginan untuk meninggalkan organisasi tersebut. Komitmen organisasional merupakan sikap kerja yang penting karena orang-orang yang memiliki komitmen diharapkan bisa menunjukan kesediaan untuk dapat bekerja lebih keras demi mencapai tujuan organisasi dan memiliki hasrat yang lebih besar untuk tetap bekerja di suatu perusahaan (Kreitner \& Kinicki, 2014:165). Jika komitmen organisasional rendah, maka loyalitas karyawan terhadap perusahaan juga akan rendah serta meningkatkan keinginan karyawan untuk tidak mempertahankan keanggotaannya di dalam perusahaan (Novriyadhi \& Riana, 2015). Karyawan yang memiliki komitmen organisasional yang rendah akan menghasilkan prestasi kerja dan produktivitas yang rendah pula (Putri et al., 2014).

Bramantara \& Dewi (2015) menyatakan bahwa terciptanya komitmen organisasional yang tinggi diawali dengan membangun hubungan antar individu, sehingga timul kepedulian maka persiapan yang baik akan menumbuhkan pemahaman dan persepsi positif sehingga orang merasa dapat menerima. Peningkatan komitmen organisasional dari setiap anggota organisasi dapat meningkat jika organisasi tersebut dapat memenuhi kebutuhan dan tujuan dari para anggotanya (Khan dan Zafar, 2013). Karyawan yang memiliki komitmen organisasional yang rendah akan menghasilkan prestasi kerja dan produktivitas yang rendah pula (Safitri, 2014). Choong et al. (2012) menyatakan bahwa karyawan yang berkomitmen dalam organisasi akan memiliki keinginan yang kuat 
untuk tetap menjadi anggota organisasi serta akan berupaya semaksimal mungkin dalam melakukan pekerjaannya. Jahanzeb et al. (2013) menyatakan adanya hubungan negatif yang kuat antara komitmen organisasional dengan turnover intention, semakin tinggi tingkat komitmen organisasional pada karyawan maka semakin rendah terjadinya turnover intention.

Penelitian ini dilakukan pada Toya Devasya Natural Hot Spring \& Camping Resort yang beralamat di Jalan Puri Bening, Toya Bungkah, Batur Kintamani, Bangli, Bali adalah pusat permandian air panas yang merupakan salah satu destinasi wiata yang memiliki daya tarik tersendiri bagi wisatawan karena menawarkan keunikan yaitu air panas alami yang mengalir dari lereng gunung Batur. Toya Devasya Natural Hot Spring \& Camping Resort sampai saat ini terus melakukan pengembangan pada usahanya yaitu terus berinovasi dalam perancangan kolam renang serta saat ini dalam masa pembangunan playground dan menyediakan banyak fasilitas lainnya bagi wisatawan seperti adventure, spa, villa, camping, coffe corner, canoing, cycling, barberque \& snack house, outing serta menyediakan jasa ruang meeting dengan fasilitas lengkap.

Tingginya tingkat turnover intention pada karyawan dapat dilihat dari data turnover yang ada pada data perputaran karyawan. Berdasarkan data awal yang didapatkan peneliti dari HRD Toya Devasya Natural Hot Spring \& Camping Resort peneliti mendapatkan permasalahan yaitu terjadinya tingkat turnover yang cukup tinggi pada data perputaran karyawan dari tahun 2014-2017. Nilai persentase turnover karyawan pada Toya Devasya Natural Hot Spring \& Camping Resort dipaparkan pada Tabel 1.

Tabel 1.

Data Perputaran Karyawan Toya Devasya Natural Hot Spring \& Camping Resort periode 2014-2017

\begin{tabular}{cccccc}
\hline Tahun & $\begin{array}{c}\text { Jumlah } \\
\text { Karyawan } \\
\text { Awal Tahun }\end{array}$ & $\begin{array}{c}\text { Jumlah } \\
\text { Karyawan } \\
\text { Masuk }\end{array}$ & $\begin{array}{c}\text { Persentase } \\
\text { Karyawan } \\
\text { Masuk }\end{array}$ & $\begin{array}{c}\text { Jumlah } \\
\text { Karyawan } \\
\text { Keluar }\end{array}$ & $\begin{array}{c}\text { Persentase } \\
\text { Karyawan } \\
\text { Keluar }\end{array}$ \\
\hline 2014 & 55 & $(2)$ & $(3)$ & $(4)$ & $=\frac{(4)}{(1)} x 100 \%$ \\
2015 & 60 & 7 & $\frac{(2)}{(1)} x 100$ & & $7,27 \%$ \\
2016 & 121 & 8 & $12,72 \%$ & 7 & $11,66 \%$ \\
2017 & 124 & 11 & $6,61 \%$ & 15 & $12,39 \%$ \\
\hline Sumber: & & $8,87 \%$ & 13 & $10,48 \%$ \\
\hline
\end{tabular}

Sumber: Data diolah, 2018

Tabel 1. menunjukan bahwa selama 4 tahun terahir tingkat turnover pada Toya Devasya Natural Hot Spring \& Camping Resort cenderung mengalami peningkatan, tingkat turnover karyawan yang tinggi mengindikasi bahwa terjadi masalah dalam suatu organisasi khususnya dalam hal ini adalah masalah terjadinya turnover intention, dari data diatas bisa dilihat bahwa tingkat turnover karyawan paling tinggi adalah pada tahun 2016 yaitu 12,39\% dimana 15 orang karyawan keluar dari perusahaan dengan berbagai alasan, yang menyebabkan banyak pekerjaan terbengkalai sehingga menurunkan kualitas pelayanan pada perusahaan terutama di bidang engginering dan perlengkapan. jika tingkat 
turnover terus mengalami peningkatan maka akan menjadi masalah serius bagi perusahaan yaitu terjadinya pemborosan dalam proses perekrutan karyawan baru, kehilangan karyawan yang berkompeten, serta terjadinya kemungkinan adanya peningkatan terjadinya turnover intention pada tahun-tahun berikutnya. Gillies (1989) menyatakan perputaran karyawan dapat dikatakan normal apabila berkisar 5-10\% pertahun dan dikatakan tinggi apabila lebih dari 10 persen pertahun, maka masalah yang terjadi adalah tingginya tingkat turnover intention baik dari karyawan dalam masa percobaan dan karyawan kontrak yang menimbulkan turnover.

Melalui pra riset dengan Wawancara awal yang telah dilakukan peneliti terhadap 10 orang karyawan dalam masa percobaan dan kontrak pada bidang engginering dan perlengkapan di Toya Devasya Natural Hot Spring \& Camping Resort yang telah keluar, mendapatkan hasil bahwa terdapat beberapa karyawan yang meninggalkan perusahaannya karena keinginannya sendiri. Karyawan tersebut pindah tempat tinggal dan telah mendapatkan pekerjaan baru yang lebih baik ditempat lain, dan beberapa karyawan lainnya mengatakan bahwa suasana kerja yang kurang nyaman, hubungan antar rekan kerja yang kurang baik serta atasan yang kurang mendukung yang menjadi penyebab mereka meninggalkan organisasi. Dalam pernyatan dari pihak HRD juga dikatakan bahwa pihak perusahaan telah memberikan THR dan asuransi kecelakaan, namun tingkat turnover masih tetap terjadi.

Turnover intention merupakan masalah serius dibidang manajemen sumber daya manusia yang berhubungan dengan perputaran tenaga kerja yang tinggi (Kumar et al., 2012). Turnover intention merupakan keinginan karyawan untuk meninggalkan perusahaan tempat ia bekerja dan mencari pekerjaan lain (Azeez \& Adeoye, 2016). Turnover Intention dapat terjadi secara sukarela maupun tidak sukarela. Tinggi rendahnya turnover intention pada karyawan pada perusahaan berdampak pula pada tinggi rendahnya perekrutan, seleksi dan pelatihan yang harus dikeluarkan perusahaan (Saeed et al., 2014). Turnover Intention adalah suatu bentuk dari karyawan untuk menarik diri pada dunia kerja dan karyawan tersebut juga memiliki hak untuk menentukan keputusan untuk tetap bekerja atau mengundurkan diri pada perusahaan (Sidharta, 2011).

Iqbal et al. (2014) ketika seseorang merasa bahwa dia tidak menyediakan sumber daya yang diinginkan dan unik atau kemampuan untuk suatu organisasi, maka ia akan mencari pekerjaan lain sesuai dengan bidangnya. Turnover intention adalah derajat kecenderungan sikap yang dimiliki oleh karyawan untuk mencari pekerjaan baru di tempat lain atau adanya rencana untuk meninggalkan perusahaan dalam masa tiga bulan yang akan datang, enam bulan yang akan datang, satu tahun yang akan datang, dua tahun yang akan datang (Dharma, 2013).

Terdapat 5 faktor yang menjadi penyebab karyawan ingin keluar dari perusahaan (Nandini \& Rochmah, 2013): 1) Faktor structural. Merupakan faktor yang berhubungan dengan pekerjaan maupun organisasi, misalnya seperti dukungan rekan kerja, rutinitas pekerjaan, dukungan atasan, ambiguitas peran, pemerataan keadilan, beban kerja, keterampilan pegawai, imbalan, keamanan kerja serta pengembangan karir. 2) Faktor pre-entry. Merupakan faktor yang meliputi kepribadian positif seperti kecenderungan untuk bahagia, dan juga 
keperibadian negatif seperti kecenderungan untuk ketidak nyamanan. 3) Faktor lingkungan. Merupakan faktor yang berhubungan dengan hal diluar pekerjaan dan organisasi. Faktor lingkungan meliputi kesempatan kerja yang tersedia di luar perusahaan, serta jumlah anggota keluarga yang ditanggung. 4) Faktor serikat pekerja. Merupakan keanggotaan seorang pegawai terhadap serikat pekerja yang dapat mempengaruhi keputusan pegawai untuk mempertahankan pekerjaan atau memutuskan untuk pindah. 5) Orientasi pekerjaan. Merupakan kepuasan kerja, komitmen organisasi dan aktifitas atau usaha pegawai untuk mencari pekerjaan alternatif diluar organisasi tempat bekerja saat ini.

Syahronica et al. (2015) menyatakan bahwa stres kerja merupakan suatu keadaan yang mempengaruhi emosi, proses berpikir, dan kondisi seseorang seperti kondisi tegang. (Harianja., 2008:192) menyatakan bahwa stres adalah suatu tanggapan penyesuaian yang diperantarai oleh perbedaan-perbedaan dan atau proses-proses psikologis akibat dari setiap tindakan lingkungan, situasi, atau peristiwa yang menetapkan permintaan psikologis dan atau fisik berlebihan kepada seseorang. Syahronica et al. (2015) menyatakan bahwa stres terjadi ketika seseorang menerima sebuah kondisi yang tidak diharapkan dari lingkungannya, sehingga menimbulkan reaksi-reaksi tertentu. Budiyono (2016) menyatakan stres yang tidak bisa diatasi dengan baik biasanya berakibat pada ketidakmampuan seseorang berinteraksi secara positif terhadap lingkungannya, baik lingkungan luar maupun lingkungan dalam perusahaan. Hasibuan (2014:204) menyatakan tingkat stres yang tinggi dapat menurunkan kinerja karyawan, kinerja karyawan yang stres pada umumnya akan menurun karena mengalami ketegangan pikiran sehingga timbul niat untuk keluar.

Stres terjadi ketika seorang karyawan tidak siap dengan lingkungan kerjanya sehingga berpengaruh pada pola berpikir, emosi, dan kondisi karyawan yang dapat menyebabkan kinerjanya menurun sehingga berdampak pada tujuan yang ingin dicapai oleh perusahaan. Stres kerja adalah perasaan yang menekan atau perasaan tertekan yang dialami karyawan dalam menghadapi pekerjaan, stres kerja ini dapat menimbulkan emosi tidak stabil, perasaan tidak tenang, suka menyendiri, cemas, gugup (R. N. Sari, 2014). Stres kerja adalah suatu kondisi ketegangan yang mempengaruhi proses berpikir, emosi, dan kondisi seseorang sehingga stres yang terlalu berlebihan dapat mengancam kemampuan seseorang untuk menghadapi lingkungan dan pada ahirnya akan menganggu pelaksanaan tugas-tugasnya (Handoko, 2014:200). Terjadinya stres kerja pada karyawan menyebabkan karyawan tersebut menjadi kurang memperhatikan keadaan sosialnya dan kurang peka terhadap orang disekitarnya sehingga menyebabkan ketidakharmonisan dalam hubungan antar karyawan. Stres terjadi ketika seorang karyawan tidak siap dengan lingkungan kerjanya sehingga berpengaruh pada pola berpikir, emosi, dan kondisi karyawan yang dapat menyebabkan kinerjanya menurun sehingga berdampak pada tujuan yang ingin dicapai oleh perusahaan. Stres kerja merupakan kesiapan individu dalam menghadapi lingkungan kerja (Nursyamsi, 2012).

Menurut Hasibuan (2014:204) menyatakan bahwa indikator stres kerja adalah sebagai berikut: 1) Beban kerja, adalah perasaan tertekan yang dirasakan oleh karyawan karena banyak tuntutan tugas yang harus diselesaikan. 2) Sikap 
pemimpin, adalah perlakuan pemimpin terhadap karyawan yang mencerminkan sikap adil. 3) Waktu kerja, waktu kerja yang tidak teratur akan membuat karyawan merasa bahwa apa yang ia lakukan tidak sebanding dengan apa yang ia dapatkan. 4) Komunikasi, komunikasi dilingkungan kerja sangatlah penting karena mampu menjalin ikatan kerjasama dan keakraban antara rekan kerja dan yang lainnya. 5) Otoritas kerja, tanggung jawab yang berlebihan juga akan menyebabkan karyawan merasa stres dalam pekerjaannya karena merasa tertekan dalam psikisnya.

Hasnain et al. (2014) mendefinisikan kepuasan kerja sebagai perasaan karyawan tentang pekerjaan mereka dan sejauh mana seorang karyawan mengalami kekompakan dengan organisasi tempatnya bekerja. Kepuasan kerja adalah sebuah tanggapan afektif atau emosional terhadap berbagai segi pekerjaan seseorang, aspek kepuasan kerja adalah adanya pemenuhan terhadap kebutuhan, tercapai atau tidaknya tujuan yang ditetapkan (Kreitner \& Kinicki, 2014).

Retnaningrum \& Musadieq (2016) semakin tinggi sebuah penilaian terhadap suatu kegiatan yang dirasakan sesuai dengan keinginan individu, maka kepuasan terhadap kegiatan tersebut semakin tinggi. Kepuasan kerja merupakan penilaian dari pekerja tentang seberapa jauh pekerjaan dapat membuatnya tetap bertahan dalam perusahaan yang dapat memuaskan kebutuhannya (Zainal et al., 2014).

Terdapat dua faktor yang mempengaruhi kepuasan kerja pada karyawan Mangkunegara (2011:120): 1) Faktor pegawai, yaitu kecerdasan IQ, kecakapan khusus, umur, jenis kelamin, kondisi fisik, pendidikan, pengalaman kerja, masa kerja, kepribadian, emosi, cara berfikir, persepsi, dan sikap kerja. 2) Faktor pekerjaan, struktur organisasi, pangkat, kedudukan, mutu pegawai, kesempatan promosi jabatan, dan hubungan kerja.

Putra \& Suana (2016) dalam penelitian menemukan bahwa ada pengaruh negatif antara komitmen organisasional terhadap turnover intention karyawan yaitu semakin tinggi komitmen organisasionalnya maka semakin rendah turnover intention yang terjadi dalam sebuah perusahaan. Jehenzeb et al. (2013) dalam penelitian menemukan bahwa ada pengaruh antara komitmen organisasional terhadap turnover intention karyawan yaitu semakin tinggi komitmen organisasionalnya maka semakin rendah turnover intention yang terjadi dalam sebuah perusahaan. Choong et al. (2012) menyatakan bahwa karyawan yang berkomitmen dalam organisasi akan memiliki keinginan yang kuat untuk tetap menjadi anggota organisasi serta akan berupaya semaksimal mungkin dalam pekerjaannya.

Hassan (2014) karyawan yang memiliki komitmen kuat terhadap organisasinya, dianggap akan tetap setia pada organisasinya sehingga tidak terjadi turnover intention. Komitmen organisasional tidak akan tumbuh dengan sendirinya, ada hubungan signifikan antara budaya kerja dengan komitmen karyawan (Robbins \& Judge, 2017). Komitmen organisasional dikonsepkan sebagai hubungan karyawan dengan organisasi tempat ia bekerja dalam berbagai nilai-nilai organisasi, yang menunjukan keinginan mereka untuk bertahan dalam organisasi tersebut (Yucel, 2012).

Teori yang digunakan dalam penelitian ini adalah social exchange theory (teori pertukaran sosial) yang digunakan untuk memandang suatu hubungan yang 
terjadi antar individu maupun kelompok. West \& Turner (2008) teori pertukaran sosial didasarkan pada ide bahwa orang memandang hubungan mereka dalam konteks ekonomi dan mereka menghitung pengorbanan lalu dibandingkan dengan penghargaan yang didapatkannya, dalam teori pertukaran sosial melibatkan dua orang atau lebih dalam interaksinya, orang-orang dalam hubungan itu tentunya akan memandang apakah suatu hubungan akan mereka lanjutkan atau tidak. Karyawan akan mengembangkan perilaku saling mendukung yang kuat dengan organisasi atau pemimpin mereka, dan dapat menyebabkan perilaku kerja yang efektif, dengan memberikan lebih banyak bantuan untuk rekan kerja mereka (Cheung \& Slavin, 2013).

Hubungan di tempat kerja memiliki unsur-unsur dari teori pertukaran sosial, karyawan percaya satu sama lain untuk melaksanakan kewajiban bersama, ketika individu diperlakukan dengan baik oleh orang lain maka akan muncul perasaan kewajiban bagi individu tersebut untuk membalasnya dengan perlakuan baik pula (Serim et al., 2014). Dalam penelitian ini hubungan antara turnover intention, stres kerja, kepuasan kerja dan komitmen organisasional dapat dijelaskan yakni ketika sebuah organisasi mampu membuat karyawan puas dalam bekerja, terhindar dari tekanan atau beban yang berlebihan yang dapat menimbulkan stress, serta mampu menciptakan komitmen organisasional yang kuat maka dengan suka rela mereka akan merasa berkewajiban untuk memberikan timbal balik bagi perusahaan atas apa yang mereka terima selama bekerja baik dalam bentuk loyalitas maupun bekerja dengan waktu yang lama di perusahaan tersebut. Suciati et al. (2015) menunjukan bahwa stres kerja berpengaruh positif terhadap turnover intention. Iqbal et al. (2014) menyatakan bahwa stres kerja berpengaruh positif terhadap turnover intention. Sewwandi \& Perere (2016) menyatakan bahwa stres kerja berpengaruh positif terhadap turnover intention. Sheraz et al. (2014) menyatakan bahwa stres kerja berpengaruh positif terhadap turnover intention. Manurung \& Ratnawati (2012) menyatakan bahwa stres kerja berhubungan positif terhadap turnover intention. Berdasarkan penjelasan diatas maka dapat dijelaskan hipotesis penelitian sebagai berikut.

$\mathrm{H}_{1}$ : Stres kerja berpengaruh positif terhadap turnover intention

Dalam penelitian Indrayanti \& Riana (2016) menemukan bahwa ada pengaruh negatif antara kepuasan kerja terhadap turnover intention. Khan \& Aleem (2014) menemukan bahwa kepuasan kerja berpengaruh negatif signifikan terhadap turnover intention. Mamewe (2015) menemukan bahwa kepuasan kerja berpengaruh negatif terhadap turnover intention. Penelitian yang dilakukan oleh Leisanyane \& Khaola (2013) menemukan bahwa terdapat korelasi negatif dan signifikan antara kepuasan kerja terhadap turnover intention. Sari et al. (2015) menyatakan kepuasan kerja berpengaruh negatif terhadap turnover intention dimana semakin puas karyawan dalam bekerja maka keinginan untuk meninggalkan organisasi semakin rendah Pawesti \& Wikansari (2016) menyatakan bahwa kepuasan kerja mempunyai hubungan yang negatif dengan turnover intention. Berdasarkan hasil di atas maka dapat disimpulkan bahwa semakin puas karyawan dalam bekerja maka karyawan enggan meninggalkan perusahaan. Dari penjelasan diatas maka dapat dijelaskan hipotesis penelitian sebagai berikut. 
$\mathrm{H}_{2}$ : Kepuasan kerja berpengaruh negatif terhadap turnover intention.

Bhatti (2016) menyatakan bahwa terdapat pengaruh negatif antara komitmen organisasional terhadap turnover intention. Satwari et al. (2016) menyatakan bahwa terdapat hubungan yang negatif antara komitmen organisasional terhadap turnover intention. Putra \& Wibawa (2014) menyatakan bahwa komitmen organisasional berpengaruh negatif terhadap turnover intention. Abdurrahim et al. (2017) menyatakan bahwa komitmen organisasional berpengaruh negatif terhadap turnover intention. Hasil yang sama didapatkan oleh Putra \& Suana (2016) menyatakan komitmen organisasional berpengaruh negatif terhadap turnover intention, dimana semakin tinggi komitmen organisasional dalam sebuah organisasi maka semakin kuat karyawan memihak pada organisasi tersebut dan enggan untuk meninggalkan organisasi.

$\mathrm{H}_{3}$ : Komitmen organisasional berpengaruh negatif terhadap turnover intention.

\section{METODE PENELITIAN}

Penelitian dilakukan di Toya Devasya Natural Hot Spring \& Camping Resort yang beralamat di Jalan Puri Bening, Toya Bungkah, Batur Kintamani, Bangli, Bali, Indonesia. Pemilihan lokasi ini dikarenakan ditemukannya indikasi permasalahan terkait niat keluar karyawan kontrak (turnover intention) serta dikarenakan belum ada penelitian sebelumnya perihal turnover intention pada Toya Devasya Natural Hot Spring \& Camping Resort.

Populasi dalam penelitian ini adalah karyawan kontrak pada Toya Devasya Natural Hot Spring \& Camping Resort yang berjumlah 137 orang. Karyawan pada Toya Devasya Natural Hot Spring \& Camping Resort tergolong dalam dua kategori yaitu pegawai dalam masa percobaan dan pegawai kontrak, pegawai dalam masa percobaan adalah pegawai yang memiliki masa kerja kurang dari tiga bulan, sedangkan pegawai kontrak adalah pegawai yang memiliki masa kerja diatas tiga bulan, dalam penelitian ini yang akan diteliti adalah pegawai kontrak karena memiliki masa kerja yang lama, dianggap telah menguasai pekerjaannya.

Sampel dalam penelitian ini adalah seluruh karyawan kontrak pada Toya Devasya Natural Hot Spring \& Camping Resort. Untuk menentukan ukuran besarnya sampel peneliti menggunakan rumus slovin Tejada \& Punzalan (2012) rumus ini dapat digunakan untuk mengetahui berapa minimal sampel yang dibutuhkan jika ukuran populasi telah diketahui.

$$
\mathrm{n}=\frac{\mathrm{N}}{1+\mathrm{N}(\mathrm{e})^{2}}
$$

Keterangan:

$\mathrm{n}=$ Jumlah Sampel/jumlah responden

$\mathrm{N}=$ Jumlah Populasi

$\mathrm{e}=$ Batas toleransi kesalahan sebesar (5\%)

137

$\mathrm{n}=\frac{137(0,05)^{2}}{1+(137)(10)}$ 


$$
\begin{aligned}
& =\frac{137}{1,3425} \\
& =102,048 \\
\mathrm{n} & =102,048 \text { dibulatkan menjadi } 102 \text { orang responden. }
\end{aligned}
$$

Tekinik analisis data yang digunakan dalam penelitin ini adalah analisis regresi linier berganda. Analisis ini digunakan untuk menerangkan besarnya pengaruh stres kerja $\left(\mathrm{X}_{1}\right)$, kepuasan kerja $\left(\mathrm{X}_{2}\right)$, komitmen organisasional $\left(\mathrm{X}_{3}\right)$ terhadap variabel terikat yaitu turnover intention $(\mathrm{Y})$. Bentuk persamaan regresi linier berganda penelitian ini adalah sebagai berikut:

$$
\mathrm{Y}=\alpha+\beta_{1} \mathrm{X}_{1}+\beta_{2} \mathrm{X}_{2}+\beta_{3} \mathrm{X}_{3}+\mathrm{e}
$$

Keterangan :

$$
\begin{array}{ll}
\mathrm{Y} & =\text { Turnover Intention } \\
\mathrm{X}_{1} & =\text { Stres kerja } \\
\mathrm{X}_{2} & =\text { Kepuasan Kerja } \\
\mathrm{X}_{3} & =\text { Komitmen Organisasional } \\
\alpha & =\text { Konstanta } \\
\mathrm{B}_{1}-\beta_{3} & =\text { Koefisien Regresi dari } \mathrm{X}_{1}-\mathrm{X}_{3} \\
\mathrm{e} & =\text { Variabel pengganggu (residual eror) yang mewakili faktor lain } \\
& \text { berpengaruh terhadap Y namun tidak dimasukan dalam model. }
\end{array}
$$

\section{HASIL DAN PEMBAHASAN}

Perkembangan yang pesat pada Toya Devasya Natural Hot Spring \& Camping Resort baru sejak 5 tahun terahir yaitu pada tahun 2014 sampai 2018, saat pemilik baru terjun langsung untuk menanganinya, banyak perombakan yang dilakukan seperti membangun konsep, membangun corporate culture, mempertajam cara pemasaran, memperkuat networking dan terus berinovasi untuk memastikan kesuksesan Toya Devasya Natural Hot Spring \& Camping Resort. Dan terbukti kunjungan wisata terus mengalami peningkatan perharinya mencapai 800 pengunjung, dan diakhir pekan mencapai 1.500 pengunjung pada tahun 2018 . Hingga saat ini Toya Devasya masih tetap eksis dan makin digemari para wisatawan baik wisatawan mancanegara maupun lokal.

Berdasarkan dari 102 responden Toya Devasya Natural Hot Spring \& Camping Resort. Karakteristik responden dilihat dari beberapa kriteria yaitu jenis kelamin, usia, pendidikan dan masa kerja, karakteristik responden diuraikan pada Tabel 2.

Tabel 2. menunjukan bahwa persentase responden laki-laki adalah 66 dengan persentase $64,7 \%$ dan responden perempuan berjumlah 35 dengan persentase $35,3 \%$. Hal ini menunjukan bahwa respondel laki-laki lebih banyak dibandingkan perempuan karyawan laki-laki banyak karena dibutuhkan pada bidang security, engginering, driver. 
Tabel 2.

Karakteristik Demografi Responden

\begin{tabular}{cccc}
\hline No. & Jenis Kelamin & Orang & $\begin{array}{c}\text { Jumlah } \\
\text { Persentase (\%) }\end{array}$ \\
\hline 1 & Laki-laki & 66 & 64,7 \\
2 & Perempuan & 35 & 35,3 \\
& Jumlah & $\mathbf{1 0 2}$ & $\mathbf{1 0 0}$ \\
No. & Tingkat Umur (Tahun) & & 67 \\
1 & 20-30 tahun & 68 & 33 \\
2 & 31-40 tahun & 34 & $\mathbf{1 0 0}$ \\
& Jumlah & $\mathbf{1 0 2}$ & 56,9 \\
No. & Pendidikan & & 38,3 \\
1 & SMA/SMK & 58 & 4,9 \\
2 & D1 & 39 & $\mathbf{1 0 0}$ \\
3 & S1 & 5 & 85,3 \\
& Jumlah & $\mathbf{1 0 2}$ & 14,7 \\
No. & Masa Kerja (Tahun) & & $\mathbf{1 0 0}$ \\
1 & 1-3 tahun & 87 & \\
2 & 3-5 tahun & 15 & $\mathbf{1 0 2}$ \\
& Jumlah & &
\end{tabular}

Sumber : Data diolah, 2018

Tabel 2. menunjukan bahwa kelompok usia paling dominan adalah pada usia 20-30 tahun dengan persentase 67\% sedangkan untuk kelompok usia terendah adalah pada usia 31-40 tahun dengan persentase 33\%. Hal ini karena di usia 20-30 tahun karyawan yang bekerja masih produktif serta banyak memberikan kontribusi seperti ide-ide dan masukan untuk perusahaan.

Tabel 2. menunjukan bahwa responden yang paling dominan adalah responden dengan pendidikan terahir SMK yaitu jurusan pariwisata dengan persentase $56,9 \%$, dan D1 yaitu $38,3 \%$, sedangkan responden yang paling rendah jumlahnya adalah responden yang pendidikan terahirnya S1 sebanyak 4,9\%. Hal ini menunjukan bahwa responden dengan pendidikan SMK dan D1 dengan persentase paling banyak karena berasal dari pendidikan yang berbasis pariwisata sehingga sesuai dengan bidang pekerjaannya pada Toya Devasya Natural Hot Spring \& Camping Resort.

Tabel 2. menunjukan bahwa masa kerja yang paling dominan dalam penelitian ini antara 1-3 tahun dengan jumlah sebanyak 87 orang atau sebesar $85,3 \%$. Hal ini terjadi karena Toya Devasya Natural Hot Spring \& Camping Resort baru saja melakukan perekrutan karyawan baru seperti yang telah diuraikan pada tabel perputaran karyawan bahwa setiap tahunnya terdapat karyawan yang keluar dari perusahaan.

Tabel 3. menunjukan bahwa seluruh indikator pernyataan dalam variabel stres kerja, kepuasan kerja, komitmen organisasional, dan turnover intention memiliki item total (Pearson Corelation) lebih besar dari 0,30 sehingga seluruh indikator tersebut memenuhi syarat validitas data dan layak digunakan sebagai instrumen penelitian.

Uji ini dilakukan terhadap instrumen dengan koefisien cronbach's alpha apabila lebih besar dari 0,60 maka instrumen yang digunakan reliabel. Tabel 4.3 menunjukan hasil uji reliabilitas. Uji ini dilakukann terhadap instrumen dengan 
koefisien cronbach's alpha $\geq 0,60$ maka yang digunakan reliabel. Uji ini bertujuan untuk mencari tahu konsistensi alat ukur yang digunakan.

Tabel 3.

Hasil Uji Validitas Instrumen

\begin{tabular}{llccc}
\hline \multirow{2}{*}{ No. } & Variabel & $\begin{array}{c}\text { Item } \\
\text { Pernyataan }\end{array}$ & $\begin{array}{c}\text { Korelasi Item } \\
\text { Total }\end{array}$ & Keterangan \\
\hline 1 & Stres Kerja $\left(\mathrm{X}_{1}\right)$ & $\mathrm{X} 1.1$ & 0,865 & Valid \\
& & $\mathrm{X} 1.2$ & 0,875 & Valid \\
& & $\mathrm{X} 1.3$ & 0,827 & Valid \\
& & $\mathrm{X} 1.4$ & 0,824 & Valid \\
2 & Kepuasan Kerja $\left(\mathrm{X}_{2}\right)$ & $\mathrm{X} 1.5$ & 0,824 & Valid \\
& & $\mathrm{X} 2.1$ & 0,819 & Valid \\
& & $\mathrm{X} 2.2$ & 0,757 & Valid \\
& & $\mathrm{X} 2.3$ & 0,799 & Valid \\
& & $\mathrm{X} 2.4$ & 0,827 & Valid \\
3 & Komitmen organisasional $\left(\mathrm{X}_{3}\right)$ & $\mathrm{X} 2.5$ & 0,870 & Valid \\
& & $\mathrm{X} 3.1$ & 0,858 & Valid \\
& & $\mathrm{X} 3.2$ & 0,853 & Valid \\
4 & Turnover Intention $(\mathrm{Y})$ & $\mathrm{X} 3.3$ & 0,785 & Valid \\
& & $\mathrm{Y} 1$ & 0,792 & Valid \\
& & $\mathrm{Y} 2$ & 0,803 & Valid \\
& & $\mathrm{Y} 3$ & 0,898 & Valid \\
\hline
\end{tabular}

Sumber: Data diolah, 2018

Tabel 4.

Hasil Uji Reliabilitas

\begin{tabular}{clcc}
\hline No & \multicolumn{1}{c}{ Variabel } & Cronbach's Alpha & Keterangan \\
& & & \\
\hline 1 & Stres Kerja (X1) & 0,894 & Valid \\
2 & Komitmen Organisasional (X2) & 0,873 & Valid \\
3 & Kepuasan Kerja (X3) & 0,773 & Valid \\
4 & Turnover Intention (Y) & 0,775 & Valid \\
\hline
\end{tabular}

Sumber: Data diolah, 2018

Hasil uji reliabilitas pada Tabel 4. menunjukan bahwa keempat instrumen penelitian yaitu stres kerja, kepuasan kerja, komitmen organisasional, dan turnover intention memiliki crinbach's alpha lebih dari 0,60. Hal ini dapat menyatakan bahwa semua instrumen reliabel sehingga dapat digunakan untuk melakukan penelitian.

Tabel 5.

Hasil Uji Normalitas

\begin{tabular}{|c|c|}
\hline Item & Unstandardized Residual \\
\hline $\mathrm{N}$ & 102 \\
\hline Kolmogrpv - Smirnov Z & 1.221 \\
\hline Assymp. Sig (2 - tailed) & 0,102 \\
\hline
\end{tabular}

Sumber : Data diolah, 2018 
Uji multikolinieritas bertujuan untuk menguji apakah pada model regresi ditemukan adanya korelasi antara variabel bebas. Nilai tolerance lebih dari 10 persen atau VIF kurang dari 10, maka dikatakan tidak ada multikoliniertitas. Hasil uji multikoliniertitas pada tabel 4.10 , menunjukan bahwa nilai tolerance variabel bebas berada diatas 0,1 dan nilai VIF berada dibawah 10. Berdasarkan hasil tersebut dapat ditarik kesimpulan bahwa model tidak terdapat gejala multikolinieritas. Uji multikolinieritas dipaparkan pada Tabel 6.

Tabel 6.

Hasil Uji Multikolinieritas

\begin{tabular}{clcc}
\hline No. & \multicolumn{1}{c}{ Variabel } & Tolerance & VIF \\
\hline 1 & Stres Kerja $\left(\mathrm{X}_{1}\right)$ & 0,695 & 1,439 \\
2 & Kepuasan Kerja $\left(\mathrm{X}_{2}\right)$ & 0,354 & 2,828 \\
3 & Komitmen Organisasional $\left(\mathrm{X}_{3}\right)$ & 0,330 & 3,032 \\
\hline Sumber: & Data diolah, 2018
\end{tabular}

Tabel 6. menunjukan hasil tingkat signifikansi tiap variabel bebas yaitu berada diatas 0,05 sehingga dapat disimpulkan model regresi terbebas dari heteroskedastisitas. Hasil uji heteroskedastisitas akan dipaparkan dalam Tabel 7.

Tabel 7.

Hasil Uji Heteroskedastisitas

\begin{tabular}{clcc}
\hline No. & \multicolumn{1}{c}{ Variabel } & thitung & Sig. \\
& & & \\
\hline 1 & Stres Kerja $\left(\mathrm{X}_{1}\right)$ & $-0,136$ & 0,892 \\
2 & Kepuasan Kerja $\left(\mathrm{X}_{2}\right)$ & 1,541 & 0,127 \\
3 & Komitmen Organisasional $\left(\mathrm{X}_{3}\right)$ & $-1,535$ & 0,179 \\
\hline
\end{tabular}

Sumber: Data diolah, 2018

Uji heteroskedastisitas bertujuan untuk mengetahui apakah dalam model regresi terjadi ketidaksamaan varians dari residual satu pengamatan ke pengamatan lain yang dilakukan dengan uji Gleser. Model regresi yang baik adalah yang tidak mengandung gejala heteroskedastisitas atau mempunyai varian yang homogen. Apabila tidak ada satupun variabel bebas yang berpengaruh signifikan terhadap nilai absolute residual atau nilai signifikansinya diatas 0,05

Model analisis linier berganda digunakan untuk mencari koefisien regresi yang akan mengetahui ketergantungan satu variabel terikat dengan satu atau lebih variabel bebas. Hasil analisis regresi linier berganda dapat dilihat pada Tabel 8 .

Berdasarkan Tabel 8. maka persamaan regresi linier berganda maka didapat hasil persamaan regresi sebagai berikut.

$$
\mathrm{Y}=4,442+0,467 \mathrm{X}_{1}-0,361 \mathrm{X}_{2}-0,246 \mathrm{X}_{3}
$$

Nilai koefisien regresi stres kerja $\left(\mathrm{X}_{1}\right)$ sebesar 0,467 yang memiliki arti bahwa stres kerja berpengaruh positif terhadap turnover intention karyawan pada Toya Devasya Natural Hot Spring \& Camping Resort, bila $\mathrm{X}_{1}$ (stres kerja) meningkat maka nilai dari turnover intention (Y) juga akan mengalami peningkatan. 
Nilai koefisien regresi kepuasan kerja $\left(\mathrm{X}_{2}\right)$ sebesar $-0,361$ memiliki arti bahwa kepuasan kerja berpengaruh negatif terhadap turnover intention karyawan pada Toya Devasya Natural Hot Spring \& Camping Resort ,bila nilai kepuasan kerja $\mathrm{X}_{2}$ meningkat maka nilai dari turnover intention (Y) akan mengalami penurunan.

Tabel 8.

Hasil Uji Regresi Linier Berganda

\begin{tabular}{lccccc}
\hline \multicolumn{1}{c}{ Model } & \multicolumn{2}{c}{$\begin{array}{c}\text { Unstandardized } \\
\text { Cofficients } \\
\text { Std.Eror }\end{array}$} & $\begin{array}{c}\text { Standardized } \\
\text { Cofficient } \\
\text { Beta }\end{array}$ & t & Sig \\
\hline Constant & 4.442 & 0,623 & & 7,126 & 0,000 \\
Stres Kerja & 0,467 & 0,099 & 0,337 & 4,727 & 0,000 \\
Kepuasan Kerja & $-0,361$ & 0,099 & $-0,363$ & $-3,633$ & 0,000 \\
Komitmen Organisasional & $-0,246$ & 0,105 & $-0,241$ & $-2,33$ & 0,022 \\
R & & & & & 0,808 \\
R Square & & & & & 0,654 \\
F Statistik & & & & & 61.639 \\
Signifikansi & & & & & 0,000 \\
\hline Sumber:
\end{tabular}

Sumber : Data diolah, 2018

Nilai koefisien komitmen organisasional $\left(\mathrm{X}_{3}\right)$ sebesar -0,246 yang memiliki arti bahwa komitmen organisasional berpengaruh negatif terhadap turnover intention karyawan pada Toya Devasya Natural Hot Spring \& Camping Resort, bila nilai komitmen organisasional $\left(\mathrm{X}_{3}\right)$ meningkat maka nilai dari turnover intention (Y) akan mengalami penurunan begitu pula sebaliknya bila nilai komitmen organisasional $\left(\mathrm{X}_{3}\right)$ turun maka nilai turnover intention (Y) akan meningkat.

Koefisien determinasi $\mathrm{R}^{2}$ berguna untuk mengukur besarnya kontribusi variabel bebas stres kerja, kepuasan kerja, komitmen organisasional terhadap variabel terikat turnover intention. Besarnya nilai $\mathrm{R}$ square adalah sebesar 0,654 yang artinya sebesar 65,4 persen variasi turnover intention dipengaruhi oleh stres kerja, kepuasan kerja, komitmen organisasional. Sedangkan sisanya sebesar 34,6 persen dipengaruhi oleh faktor lain diluar model penelitian ini.

Uji kelayakan model (uji F) digunakan untuk mengetahui adanya pengaruh antara variabel bebas secara bersama-sama terhadap variabel terikat. Berdasarkan hasil yang terdapat pada Tabel 8 nilai $F$ statistik sebesar 61.639 dan nilai signifikannya sebesar $0,000 \leq 0,05$ maka dapat disimpulkan adanya pengaruh yang signifikan antara stres kerja, kepuasan kerja dan komitmen organisasional terhadap turnover intention.

Berdasarkan Tabel 8. stres kerja memiliki nilai koefisien beta positif sebesar 0,467, dengan signifikansi uji t sebesar sebesar 0,467 lebih kecil dari $\alpha=0,05$ maka $\mathrm{H}_{0}$ ditolak. Hasil ini mendukung hipotesis $\mathrm{H}_{1}$ yang menyatakan stres kerja berpengaruh positif terhadap turnovr intention pada karyawan Toya Devasya Natural Hot Spring \& Camping Resort, dimana semakin tinggi tingkat stres kerja yang dialami karyawan maka semakin tinggi juga tingkat turnover intention yang terjadi. 
Berdasarkan Tabel 8. kepuasan kerja memiliki nilai koefisien beta negatif sebesar $-0,361$, dengan signifikansi uji t sebesar 0,000 lebih kecil daripada $\alpha=$ 0,05 , maka $\mathrm{H}_{0}$ ditolak. Hasil ini mendukung hipotesis $\mathrm{H}_{2}$ yang menyatakan bahwa kepuasan kerja berpengaruh negatif terhadap turnover intention pada karyawan Toya Devasya Natural Hot Spring \& Camping Resort,dimana semakin tinggi kepuasan kerja pada karyawan maka semakin rendah terjadinya turnover intention.

Berdasarkan Tabel 8. komitmen organisasional memiliki nilai nilai koefisien beta negatif sebesar 0,246, dengan signifikansi uji t sebesar 0,022 lebih kecil dari 0,05 , maka $\mathrm{H}_{0}$ tolak. Hasil ini mendukung hipotesis $\mathrm{H}_{3}$ yang menyatakan bahwa komitmen organisasional berpengaruh negatif terhadap turnover intention pada Toya Devasya Natural hot spring \& camping resort, dimana semakin tinggi tingkat komitmen organisasional maka semakin rendah terjadinya turnover intention.

Penelitian ini mendapatkan hasil yang sama dengan hipotesis satu $\left(\mathrm{H}_{1}\right)$ yang menyatakan bahwa stres kerja berpengaruh positif terhadap turnover intention. Hasil analisis uji hipotesis menunjukan bahwa stres kerja memiliki pengaruh positif dan signifikan terhadap turnover intention, dengan nilai koefisien regresi sebesar 0,467 . Nilai positif dari koefisien regresi variabel stres kerja memiliki arti bahwa stres kerja yang tinggi dapat meningkatkan terjadinya turnover intention pada karyawan. Temuan ini didukung oleh hasil penelitian Iqbal et al. (2014) yang mengemukakan bahwa stres kerja berpengaruh positif terhadap turnover intention. Yani et al. (2016) menemukan bahwa stres kerja memiliki pengaruh yang positif terhadap turnover intention ini artinya jika tingkat stres kerja meningkat maka keinginan karyawan untuk keluar juga semakin meningkat. Hasil ini juga didukung oleh pendapat Suciati et al. (2015) menunjukan bahwa stres kerja berpengaruh positif terhadap turnover intention, Sewwandi \& Perere (2016) menyatakan bahwa stres kerja berpengaruh positif terhadap turnover intention.

Penelitian ini mendapatkan hasil yang sesuai dengan hipotesis dua $\left(\mathrm{H}_{2}\right)$ yang menyatakan bahwa kepuasan kerja berpengaruh negatif terhadap turnover intention. Hasil analisis uji hipotesis menunjukan bahwa kepuasan kerja memiliki pengaruh negatif dan signifikan terhadap turnover intention, dengan nilai koefisien regresi sebesar -0,361. Nilai negatif dari koefisien regresi variabel kepuasan kerja memiliki arti bahwa kepuasan kerja yang tinggi akan menurunkan tingkat turnover intention karyawan. Temuan ini didukung oleh hasil penelitian Khan \& Aleem (2014) menyatakan kepuasan kerja berpengaruh negative terhadap turnover intention dimana semakin puas karyawan dalam bekerja maka keinginan untuk meninggalkan organisasi semakin rendah. Mamewe (2015) menyatakan bahwa kepuasan kerja mempunyai hubungan yang negatif dengan turnover intention.

Penelitian ini mendapatkan hasil yang sesuai dengan hipotesis tiga $\left(\mathrm{H}_{3}\right)$ yang menyatakan bahwa komitmen organisasional berpengaruh negatif terhadap turnover intention. Hasil analisis uji hipotesis menunjukan bahwa komitmen organisasional memiliki pengaruh negatif dan signifikan terhadap turnover intention, dengan nilai koefisien regresi sebesar -0,246. Nilai negatif dari koefisien regresi variabel komitmen organisasional memiliki arti bahwa komitmen 
organisasional yang tinggi akan menurunkan tingkat turnover intention karyawan. Temuan ini didukung oleh penelitian Putra \& Suana (2016) menyatakan bahwa komitmen organisasional berpengaruh negatif terhadap turnover intention, dimana semakin tinggi komitmen organisasional dalam sebuah organisasi maka semakin kuat karyawan memihak pada organisasi tersebut dan enggan untuk meninggalkan organisasi, Bhatti (2016) menyatakan bahwa terdapat pengaruh negatif antara komitmen organisasional terhadap turnover intention.

Penelitian ini mengkonfirmasi model pengaruh dari stres kerja, kepuasan kerja, komitmen organisasional terhadap turnover intention. Hasil dari model teoritis tersebut menjelaskan bahwa stres kerja, kepuasan kerja, dan komitmen organisasional secara langsung mempengaruhi turnover intention. Hasil penelitian ini menjelaskan pentingnya peran stres kerja, kepuasan kerja, dan komitmen orgnisasional agar dapat menekan terjadinya turnover intention sehingga dapat menurunkan niat karyawan untuk keluar dari perusahaan.

Cakupan wilayah penelitian ini kurang luas karena hanya dilakukan di satu perusahaan dengan karakteristik responden yang kurang beragam. Penelitian ini hanya sebatas meneliti empat variabel mengenai stres kerja, kepuasan kerja, komitmen organisasional, turnover intention. Penelitian selanjutnya disarankan untuk dapat menambah variabel lain yang mampu mempengaruhi variabel turnover intention. Jarak tempuh peneliti dengan lokasi penelitian cukup jauh sehingga waktu dalam penyelesaian penelitian cukup lama. Tingkat kejujuran responden masih diragukan karena peneliti hanya menggunakan kuesioner dan wawancara dalam penelitian ini. Penelitian ini hanya dilakukan dalam kurun waktu tertentu sedangkan lingkungan setiap saat berubah, sehingga penelitian ini perlu dilakukan kembali di masa mendatang.

\section{SIMPULAN}

Stres Kerja memiliki pengaruh positif terhadap turnover intention. Hal ini berarti bahwa tinggi tingkat stres kerja yang dialami karyawan maka tingkat turnover intention juga semakinmeningkat. Kepuasan kerja memiliki pengaruh negatif terhadap turnover intention. Hal ini mengindikasikan bahwa semakin tinggi kepuasan kerja karyawan maka turnover intention akan semakin rendah. Komitmen organisasional berpengaruh negatif terhadap turnover intention. Hal ini berarti bahwa karyawan dengan komitmen organisasional yang tinggi akan memiliki tingkat turnover intention yang rendah.

Pihak perusahaan hendaknya mengkaji ulang dalam pemberian tugas pada karyawan, agar karyawan tidak terbebani dengan pekerjaan yang begitu banyak sehingga menimbuulkan stres dalam bekerja dengan cara memberikan pekerjaan sesuai dengan keahliannya dan melakukan pelatihan agar karyawan tidak berniat meninggalkan organisasi. Pihak perusahaan hendaknya dapat lebih meningkatkan kepuasan kerja karyawan. Hal tersebut dapat diwujudkan dengan cara menambah frekuensi training guna meningkatkan keterampilan karyawan dalam bekerja sehingga karyawan merasa puas dalam melakukan pekerjaannya. Perusahaan diharapkan memberlakukan sistem rotasi kerja pada karyawan dengan bidang yang berbeda sehingga karyawan tidak merasa bosan dalam bekerja. Pihak perusahaan hendaknya dapat meningkatkan komitmen organisasional pada 
karyawan dengan cara membuat situasi dalam perusahaan terasa nyaman dengan meningkatkan sarana dan fasilitas kerja yang ada sehingga karyawan loyal terhadap perusahaan.

\section{REFERENSI}

Abdurrahim, Anisah, H. U., \& Dewi, M. S. (2017). Pengaruh kepuasan kerja dan komitmen organisasi terhadap. Jurnal Ilmiah Manajemen, I(2), 1-11.

Azeez, R., \& Adeoye, A. O. (2016). Job Satisfaction, Turnover Intention and Organizational Commitment Job Satisfaction, Turnover Intention And Organizational. Journal of Management Research, 8(2), 102-114.

Bhatti, M. H. (2016). Impact of Organization Commitment on Turnover Intention : Mediating Role of Job Contentment, 8(13), 24-39.

Bramantara, G. N. B., \& Dewi, A. A. S. K. (2015). Pengaruh Kepuasan Kerja dan Komitmen Organisasional Terhadap Turnover Intention Karyawan Pada Krisna Oleh-Oleh Khas Bali III. E-Jurnal Manajemen Unud, 4(1), 1-20.

Budiyono, R. (2016). Analisa Pengaruh Kepuasan Kerja, Stres Kerja, dan Komitmen Organisasi Terhadap Turnover Intention: Studi Pada PT. Duta Service Semarang. Jurnal STIE Semarang, 8(1), 37-53.

Chandio, A., \& Javed. (2015). Pemodelan Hubungan Yang Tidak Jelas Pengembangan Karir dan Ketidakpuasan Kerja, Stres Kerja dan Karyawan Terhadap Turnover Intention. International Research Journal of Arts \& Hummanities, 4(1), 1016-9342.

Cheung, A. C. K., \& Slavin, R. E. (2013). The effectiveness of educational technology applications for enhancing mathematics achievement in K-12 classrooms: A. Educational Research Review, 9, 88-113. https://doi.org/10.1016/j.edurev.2013.01.001

Darmawati, A., \& Indartono, S. (2015). Pengaruh Kepuasan Kerja Terhadap Organizational Citizenship Behaviour dengan Komitmen Organisasi Sebagai Variabel Mediasi. Jurnal Ilmu Manajemen, 12(2), 49-64.

Dharma, C. (2013). Hubungan antara Turnover Intention dengan Komitmen Organisasional di PT. X Medan. Jurnal Ekonomi Dan Bisnis Jurusan Administrasi Niaga, 1(2), 1-9.

Gillies, D. A. (1989). Manajemen Keprawatan: Suatu Pendekatan Sistem (2nd ed.). Llioni: WB Saunders Company.

Handoko, T. H. (2014). Manajemen Personalia dan Sumber Daya Manusia. Yogyakarta: BPFE. 
Harianja., M. T. E. (2008). Manajemen Sumber Daya Manusia Pengadaan, Pengembangan, Pengkompensasian dan Peningkatan Produktivitas Pegawai. Jakarta: PT Grasindo.

Hasnain, N., Alam, S. A., \& Hasan, Z. (2014). Job Insecurity and Job Satisfaction as Correlates of Organizational Commitment In Middle-level Executives of Public and Private sector Banks. International Journal of Academic Research in Psychology, 1(2), 120-135. https://doi.org/10.6007/IJARP/v1-i2/1310

Hassan, R. (2014). Factors Influencing Turnover Intention Among Technical Employees in Information Technology Organization: A Case Of Xyz (M) Sdn. Bhd. International Journal of Arts and Commerce, 3(9), 120-137.

Indrayanti, D. P., \& Riana, I. G. (2016). Pengaruh Kepuasan Kerja Terhadap Turnover Intention Melalui Mediasi Komitmen Organisasional Pada PT. Ciomas Adisatwa di Denpasar. E-Jurnal Manajemen Unud, 5(5), 2727-2755. Retrieved from https://ojs.unud.ac.id/index.php/Manajemen/article/view/20246

Iqbal, S., Ehsan, S., Rizwan, M., \& Noreen, M. (2014). The impact of organizational commitment, job satisfaction, job stress and leadership support on turnover intention in educational institutes. International Journal of Human Resource Studies, 4(2), 181-195.

Khan, A. H., \& Aleem, M. (2014). Impact of job satisfaction on employee turnover: An empirical study of Autonomous Medical Institutions of Pakistan, 7(1), 122-132. https://doi.org/10.14254/2071-8330.2014/7-1/11

Khan, M. S., Khan, I., Muhammad, G., Khan, S., Nawaz, A., \& Khan, F. (2014). The Impact of Job Satisfaction and Organizational commitment on the Intention to leave among the Academicians, 4(2), 114-131. https://doi.org/10.6007/IJARBSS/v4-i2/562

Kreitner, R., \& Kinicki, A. (2014). Perilaku Organisasi (9th ed.). Jakarta: Salemba Empat.

Leisanyane, K., \& Khaola, P. (2013). The Influence of Organisational Culture and Job Satisfaction on Intentions to Leave: The Case of Clay Brick Manufacturing Company in Lesotho. EASSRR, 29(1), 59-75. https://doi.org/10.1353/eas.2013.0001

Mamewe, L. (2015). Stres Kerja dan Iklim Organisasi serta Pengaruhnya terhadap Turnover Internation dengan Kepuasan Kerja sebagai Variabel Pemediasi. Jurnal Riset Bisnis Dan Manajemen, 3(4), 358-369.

Manurung, M. T., \& Ratnawati, I. (2012). Analisis Pengaruh Stres Kerja dan 
Kepuasan Kerja terhadap Turnover Intention Karyawan (Studi pada STIKES Widya Husada Semarang). Diponegoro Journal of Management, 1(2), 145157.

Nandini, N., \& Rochmah, T. N. (2013). Penyebab Turnover Intention Pada Pegawai Instalasi Gizi Rumah Sakit PHC Surabaya. Jurnal Administrasi Kesehatan Indonesia, 1(3), 272-279.

Novriyadhi, R. O., \& Riana, G. (2015). Keadilan Organisasional Terhadap Kepuasan Kerja dan Komitmen Organisasi Pada PT Astra International Auto 2000 Denpasar. E-Jurnal Manajemen Unud, 4(6), 1753-1770.

Pawesti, R., \& Wikansari, R. (2016). Pengaruh Kepuasan Kerja Terhadap Intensi Turnover Karyawan di Indonesia. Jurnal Ecopsy, 3(2).

Putra, I. G. S., \& Wibawa, I. M. A. (2014). Pengaruh Stres Kerja dan Komitmen Organisasi Terhadap Kepuasan Kerja Berdasarkan Gender pada Warong Miyabi Bali. E-Jurnal Manajemen Universitas Udayana, 3(9), 2745-2766. Retrieved from https://ojs.unud.ac.id/index.php/Manajemen/article/view/9319

Putra, I. P. D. S. S., \& Suana, I. W. (2016). Pengaruh Preceived Organizational Support dan Organisasional Terhadap Turnover Intention Karyawan. EJurnal Manajemen Unud, 5(10), 6260-6287.

Putri, W. S. I., Rahardjo, K., \& Djudi, M. (2014). Analisa Perbedaan Komitmen Organisasi Berdasarkan Status Karyawan (Studi Pada Karyawan PT. Kebexindo Tractors Tbk. Representatife Office Bengkulu). Jurnal Administrasi Bisnis (JAB), 10(1), 1-7.

Retnaningrum, A. K., \& Musadieq, M. Al. (2016). Pengaruh Work Family Conflict Terhadap Kepuasan Kerja dan Kinerja. Jurnal Administrasi Bisnis (JAB), 36(1), 72-81.

Robbins, S. P., \& Judge, T. A. (2017). Perilaku Organisasi (16th ed.). Jakarta: Salemba Empat.

Saeed, I., Waseem, M., Sikander, S., \& Rizwan, M. (2014). The relationship of Turnover intention with job satisfaction, job performance, Leader member exchange, Emotional intelligence and organizational commitment. International Journal of Learning \& Development, 4(2).

Sari, N. R., Hakam, M. S., \& Susilo, H. (2015). Pengaruh Kepuasan Kerja Terhadap Turnover Intention (Studi pada AJB Bumiputera 1912 Kantor Wilayah Jatim II/Malang). Jurnal Administrasi Bisnis (JAB), 27(1), 1-8. 
Sari, R. N. (2014). Pengaruh Kepuasan Kerja, Stres Kerja dan Komitmen Organisasional Terhadap Turnover Intention Pada Hotel Ibis Yogyakarta. Universitas Negeri Yogyakarta.

Satwari, T., Musadieq, M. Al, \& Afrianty, T. W. (2016). Pengaruh Komitmen Organisasional terhadap Turnover (Survei pada Karyawan Hotel SwissBelinn Malang). Jurnal Administrasi Bisnis, 40(2), 177-186.

Serim, H., Demirbağ, O., \& Yozgat, U. (2014). The Effects of Employees' Perceptions of Competency Models on Employability Outcomes and Organizational Citizenship Behavior and the Moderating Role of Social Exchange in this Effect. Procedia - Social and Behavioral Sciences, 150, 1101-1110.

Sewwandi, D. V. ., \& Perere, G. D. . (2016). The Impact of Job Stress on Turnover Intention: A Study of Reputed Apparel Firm in Sri Lanka. 3rd International HRM Conference, 3(1), 223-229.

Sheraz, A., Wajid, M., Sajid, M., \& Rizwan, M. (2014). Antecedents of Job Stress and its impact on employee' $\mathrm{s}$ Job Satisfaction and Turnover Intentions, $4(2), 204-226$.

Suciati, Haryono, A. T., \& Minarsih, M. M. (2015). Job Insecurity and Job Stress Effect of Turnover Intention on PT. Berkat Abadi Surya Cemerlang Semarang (HO), 1-12.

Syahronica, G., Hakam, M. S., \& Ruhana, I. (2015). Pengaruh Kepuasan Kerja Dan Stress Kerja Terhadap Turnover Intention (Studi Pada Karyawan Epartemen Dunia Fantasi PT. Pembangunan Jaya Ancol, Tbk). Jurnal Administrasi Bisnis (JAB), 20(1), 1-6.

Tejada, J. ., \& Punzalan, J. R. B. (2012). On The Misuse of Slovin's Formula. The Philippine Statistician, 61(1), 129-136.

Waspodo, A. A., Handayani, N. C., \& Paramita, W. (2013). Pengaruh Kepuasan Kerja dan Stres Kerja Terhadap Turnover Intention Pada Karyawan PT. Unitex. Jurnal Riset Manajemen Sains Indonesia (JRMSI), 4(1), 97-115.

West, R., \& Turner, L. (2008). Pengantar Teori Komunikasi: Analisis dan Aplikasi. Jakarta: Salemba Humanika.

Yani, N. W. M. S. A., Sudibya, I. G. A., \& Rahyuda, A. G. (2016). Pengaruh Work-family Conflict dan Stres Kerja Terhadap Kepuasan Kerja dan Turnover Intention Karyawan Wanita. E-Jurnal Ekonomi Dan Bisnis Universitas Udayana, 5(3), 629-658. 
E-Jurnal Manajemen, Vol. 8, No. 10, 2019 : 5907-5927

Zainal, V. R., Hadah, M. D., \& Ramly, H. M. (2014). Kepemimpinan dan Perilaku Organisasi (4th ed.). Jakarta: PT. Raja Grafindo Persada. 